\title{
Translation Procedures in Translating English Poem into Indonesian
}

Ida Ayu Made Puspani*, Ni Luh Ketut Mas Indrawati

Faculty of Arts Udayana University, Jalan Pulau Nias No 13 Denpasar Bali Indonesia

Corresponding Author: Ida Ayu Made Puspani, E-mail: made_puspani@unud.ac.id

\section{ARTICLE INFO}

Article history

Received: April 04, 2018

Accepted: July 13, 2018

Published: November 01, 2018

Volume: 7 Issue: 6

Advance access: September 2018

Conflicts of interest: None

Funding: None

\begin{abstract}
This paper aims at analyzing the translation procedures applied in poetic translation. A poem as a part of literary work is written for an aesthetic value by the author to convey his/her message to the readers. In poetic translation it is very important for the translator to know not only the two language systems and cultures within which he/she operates but also should acquire the knowledge of literary work of the source language (SL) in order to be able to transfer the message to the closest equivalent to the target language (TL). Poems usually contain many figurative expressions. The ability of the translator in defining the equivalent of the figurative expressions in SL will depend on his/her knowledge to observe their meaning before transferring them to the TL. The data of this study were taken from an English poem entitled 'The Nocturne in the Corner Phonebox ' written by an Australian poet Andrew Taylor and translated into Indonesian 'Nyanyian Malam di Gardu Telpun `by Sapardi Djoko Damono. The Theory applied is the theory of translation proposed by Newmark (1988: 81-111) related to the procedures of translation. The research is qualitative and the data were descriptively analyzed. The findings show that modulation, shift, equivalent, transposition, descriptive equivalent are utilized as the translation procedures. Some of the figurative expressions such as hyperboles, personifications, were translated into descriptive equivalent and some are converted to the hyperboles and personifications in the TL.
\end{abstract}

Key words: Translation, Culture, Equivalent, Figurative Expressions and Procedures

\section{INTRODUCTION}

Translation involves the transfer of meaning from SL to the TL. Meaning of the SL text should be retained in the TL text therefore the readers of the TL obtain similar comprehension of the message of the SL (Larson, 1984). Poetic translation is dense with implied meaning being expressed by the writer to the reader. The aesthetic meaning in every word presented in each line of the poem may convey not only the denotative meaning but also connotative meaning. It is presented in order to create figures of speech or figurative senses in elaborating the message of the writer to be delivered to the readers.

Hence the figures of speech might convey implied meaning in the SL poem so the translator should understand the use of the figure of speech in order to be able to translate it into the TL by retaining to the closest equivalent. As poem is presented in certain form and structure of the SL; a translator when transferring the meaning of the SL,she/he might have to find a way or to make decision to change the form in order to retain the meaning so the readers of the TL poem will have similar impression as expected by the writer of the SL poem. As stated by Nida and Taber (1969, p.126) "the conflict between the dictates of form and content becomes especially important where the form of the message is highly specialized" as it is in poetry. Poetry is a means of expressing one nation's feelings and attitudes.

Discussing the translation of poetry is very stimulating since its involved analyzing the same meaning expressed in two different languages with their different cultures. There are some previous studies on poetic translation reviewed in this study they are: (1) 'Translatability and Poetic Translation' by Aiwei (2005). Aiwei states that literary translation especially poetic translation has more concern on the density of the message with each words on every line of the verse, compared to scientific text or general text. The former has unbridled connotation, lack of argumentative progression, vagueness, imagination or intuition, emotion and truth to the ideal and universal while the later has denotative adequacy, logical expository, argumentative progression, precision, intellect, reason and truth to particular. She also describes that the function of a literary translation as an anaesthetic value, where the receivers/readers take the translator 's interpretation for the intention of the writer as the sender of the message in the poem. In order to attain the faithfulness of the intention there are some requirements should be done by the translator; the interpretation should be identical to the writer's intention; it should be verbalized in such a way that the target text is able to attain the same function as the target 
culture, the target receiver of the text world of translation in the same way as the source receiver understood it. (2) Venuti (2011) states in his article that to translate a poem irrespective of the language, culture or historical moment has often intended to create a poem in the receiving situation to support effects that may strive to maintain equivalence to the source text. As the translation is written in different language for a different culture; the poem as the object of the translation unavoidably disappears during the translation process, replaced by a network of signification inter-textual, inter-discursive, inter-semiotic that is rooted essentially in the receiving situation. Therefore poetry translation tends to release language from narrowly defined communicative function of a formal semantic invariant contained in the source text.

Related to the previous discussion, this study has two problems to be discussed, they are: first, what are the procedures applied in transferring the SL poem into the TL. Secondly, what are the equivalent meanings of the SL figurative expressions in the TL poem? Therefore the aims are to find out the procedures applied in transferring the SL poem into the TL and analyze the equivalent meaning of certain figurative expressions.

\section{METHODOLOGY AND THEORETICAL FRAMEWORK}

Poem translation presents special challenges to translators in addition to its content, as poetic discourse that differentiate it from common discourse; it is form and content which cannot be separated. Its content is highly language-bound. Newmark (1988) states: "the translation of poetry is the field where most emphasis is normally put on the creation of a new independent poem and where literal translation is usually condemned". The components of a poem comprises of rhythm, rhyme, tone, deviation from institutional linguistic codes, musicality produced through meters. The emphasize lies on the artistic and the subjective side. In order to find equivalent image of the original poem in the TL, therefore trans-creation, transformation, and transposition form an important role in it. The outcome is not only the semantic information of the original poem conveyed but also its aesthetic information including the shape, the construction and the aesthetic state of it.

Qualitative- descriptive method is applied in obtaining the data of the study; by observing carefully through intensive reading of the SL poem and its translation of each line in each stanza to find out the types of procedures applied by the translator and how the achievement of the meaning equivalence of the SL in the TL related to figurative expressions. As stated by Newmark (1988), the procedures can be applied i.e.:(1) transference in chase the translator is faced with the choice to translate a word unfamiliar in the TL, which in principle should be a cultural word whose referent is peculiar to SL culture; (2) naturalization is type of transference and adapts the SL words first to the normal pronunciation then the normal morphology of the TL; (3) cultural equivalent procedure is an approximate translation where the SL cultural word is transferred by a TL cultural word; (4) functional equivalent is a procedure applied in translating cul- tural word, requires the use of cultural free word sometimes with a new specific term thus naturalizes the use of the SL word;(5) descriptive equivalent is a procedure that has to weigh against its function. (6) synonymy where a sense of near equivalent to a SL word in a context, or when the SL word does not have clear one to one equivalent in the TL; (7) shift (Catford`s term) or transposition (Vinay and Darbelnet) is a translation procedure involving change in grammar of the SL in the TL, one type of change from singular to plural; (8) modulation as defined by Vinay and Darbelnet is a type of procedure to explain variation through change of point of view, perspective or change of thought;(9) compensation is happened when loss of meaning, sound effect, metaphor or pragmatic effect in one part of the sentence is compensated in another part; (10)paraphrase or descriptive equivalent is an explanation of meaning segment of a text; and couplet is couplet, triplet and quadruplet's combine of two, three or four of the previous mentioned procedures.

Newmark (1988) states that translation of metaphor in literary work comprises figurative expression of the translation of a certain words, abstraction of personification. Collocation of word which is not literally signify to describe one thing for another, all polysemy words and phrasal verbs are potentially metaphorical words.He also emphasizes that in poem there is the tendency of metaphor exists to give a commutative effect which needs particular perception. A translator should understand the meaning of the metaphor of the SL before transferring it to the possible equivalent meaning in the TL. In line with metaphor translation Newmark (1988) proposed some procedures that can be applied, i.e.: (1) reproducing the image in the TL, (2) replacing the image in the TL with the standard form of TL, (3) translating metaphor to simile, (4) translating metaphor to simile with sense, (5) conversion of metaphor with sense, (6) using the same metaphor combined with sense and (7) deletion.

In translating metaphor, the translator can transfer the meaning with the possible procedure that can be applied and adjusted to the cultural background of the TL. The main problem that is faced by him/her lies on the word meaning. There is no exact equivalent of word from one language to another, so the transfer of word meaning from SL to TL can be avoided by the existence of shift of meaning, extension, narrowed meaning, up to total changes related to figure of speech which often occurs in a poem. This is due to each language using different reference of figure of speech which has the same meaning. As in the English idiom 'don 't cry over spiltmilk', this idiom in Indonesian is equivalent to " $n a s i$ telah menjadi bubur'. In which both idioms in English and in Indonesian have the same meaning that is: it is no need to regret of what had happened.

\section{DISCUSSION}

Related to the data of the SL poem and its translation, the analysis of the meaning of each stanza and lines are explored in terms of their equivalent in the TL related to the application of translation procedures and the meaning implication of the TL. The poem 'The Nocturne in the Corner Phoneboxis an English poem written by an Australian writer, Andrew 
Taylor and its translation is 'Nyanyian Malam di Gardu Telpun translated by Sapardi Djoko Damono. The poem comprises of four stanzas and each stanza comprises of seven lines, the total numbers of the lines are twenty eight.

\section{Analysis of Translation Procedures of the First Stanza}

The analysis of the first stanza is preceded by the analysis of the title of the poem 'The Nocturne in the Corner Phonebox' is translated into 'Nyanyian Malam di Gardu Telpun '. Nocturne in the SL has the meaning of a short composition of a romantic character suggestive of the night typically for piano; it relates to the sound of music at night. As stated in the poem it is not the sound of a piano but it is the sound of a trombone being mentioned in the first line of the $1^{\text {st }}$ stanza. The translator converted the meaning of Nocturne into Nyanyian Malam, the translator applied the procedure of modulation by changing point of view of the SL into the meaning content of the sound as it is related to the duration of night time the melodious sound appeared by replacing it in the TL as Nyanyian Malam in order to give the same impact of the situation when the sound is being heard. And 'in the Corner Phonebox ' is translated into' di Gardu Telpun'. The word 'corner' is not being translated as it is common in Indonesian the phonebox in certain place where it is easy for people to do telephone call, it is normally placed in certain corner of a park or public place so the translator left the word 'corner' un-transferred without changing the meaning of the whole statement. The word 'Phonebox' is translated into 'gardu telpun ' the word 'gardu' in Indonesian is a small place where the security guard dwell during his duty or a small place to sell something as a small stall but on this translation; the translator applied the procedures of functional equivalent, where the SL word is replaced by a term that generalizes a type of place that resembles the TL.

The first stanza of the poem comprises of seven lines as described in the following table.
The first line of the first stanza of the SL poem 'Someone is playing a trombone' is translated into 'Seseorang sedang meniup trombone' The procedure of shift is applied in the transfer to retain the meaning of the SL in the TL The verb phrase in the SL 'is playing' is translated into 'sedang meniup' in the TL, the aspect of present continuous in the SL is replaced by a lexical aspect 'sedang' which indicates an action is in progress in the TL.In terms of meaning equivalent of the SL line and its translation in the TL, though the translator applies shift procedure the meaning of the SL line is retained in the TL line.

The second line 'in the telephone box outside my room' is translated into `di Gardu telpun di luar kamarku'; the prepositional phrase'outside my room' in SL is equivalent to 'di luar kamarku'.The SL noun phrase (NP) comprises of Prep. (Preposition)+ Poss. marker+ noun (N/head) and the TL NP comprises of prep $+\mathrm{N}+\mathrm{NP}(\mathrm{N}+$ poss. marker $)$, a grammatical shift is applied due to the different system between the SL and the TL.

The $3^{\text {rd }}$ line 'It's 1 a.m' is translated literally into the TL 'Pukul 1 pagi'. And the $4^{\text {th }}$ line 'and he 's removed the globe' is translated into 'dania telah mencopot bola lampu'; the SL NP' the globe` is translated into TL compound noun 'bola lam$p u^{\prime}$ there is a shift from the SL into the TL. The $5^{\text {th }}$ line ' He 's playing a melancholy cadenza' is translated into 'Ia memainkan suatu kadensa yang memilukan'; the NP 'a melancholy cadenza' is translated into 'suatu kadensa yang memilukan'; the SL NP consists of indef. Art. + Adj. + N (Head) and the TL NP comprises of art. $+\mathrm{N}+$ Rel. Clause; there is shift in grammar. The $6^{\text {th }}$ line 'probably over the S.T.D'; the NP 'the S.T.D' is translated into N 'interlokal which means it is not a local phone call- a phone call made to other city which is equivalent in meaning to S.T.D (Subscriber Trunk Dialing) is also called as a telephone system allowing subscriber to dial trunk calls without operator assistance. It has equivalent meaning with the TL 'interlokal', the translator applies cultural equivalent procedures to retain the meaning.

Table 1. Stanza 1

\begin{tabular}{|c|c|c|}
\hline Line & SL & TL \\
\hline 1 & Someone is playing a trombone & 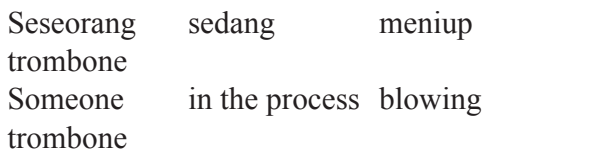 \\
\hline 2 & In the telephone box outside my room & $\begin{array}{l}\text { Di Gardu telpun di luar kamarku } \\
\text { at box telephone outside room- my }\end{array}$ \\
\hline 3 & It's 1 a.m., & $\begin{array}{l}\text { Pukul } 1 \text { pagi, } \\
\text { Hour } 1 \text { morning }\end{array}$ \\
\hline 4 & And he's removed the globe & $\begin{array}{lll}\text { Dan ia } & \text { telah } & \text { mencopot } \\
\text { bola lampu } & & \\
\text { and he/she } & \text { perfect marker } & \text { take-out } \\
\text { bulb } & & \end{array}$ \\
\hline 5 & He`s playing a melancholy cadenza & $\begin{array}{lcccc}\text { Ia } & \text { suatu } & \text { kadensa } & \text { which memilukan } \\
\text { he/she } & \text { a } & \text { cadenza } & \text { yang } & \text { heart-break }\end{array}$ \\
\hline 6 & Probably over the S.T.D & $\begin{array}{l}\text { Barangkali interlokal } \\
\text { Probably long distance call }\end{array}$ \\
\hline 7 & To his girl in sydney & $\begin{array}{llll}\text { Kepada } & \text { pacarnya } & \text { di } & \text { Sydney } \\
\text { to } & \text { fiancee-his } & \text { in } & \text { Sydney }\end{array}$ \\
\hline
\end{tabular}


The $7^{\text {th }}$ line of the first stanza 'to his girl in Sydney' the complement of the previous sentence in the $6^{\text {th }}$ line is translated to `kepada pacarnya di Sydney`; the NP `his girl` (Poss. marker $+\mathrm{N})$ is translated into 'pacarnya ' (NPàN+Poss.-nya) a grammatical shift is applied in order to retain the meaning of the SL in the TL.

\section{Analysis of Translation Procedures of the Second Stanza}

The Table 2 also comprises of 7 lines, in this stanza the writer (I) is imagining what happened to the boy who made the S.T.D and was playing the trombone in the telephone box; how was his girlfriend when receiving the long distance call and wondering whether the boy has enough small change to make the call or probably he asked his girlfriend to do reverse charge?.

The analysis initiates from line 8 'I can imagine ... 'is translated into 'bisa kubayangkan... '; the statement in the $T L$ is in the form passive, in order to retain the aesthetic value of the SL in the TL; if the it is translated into the same structure as the SL (active) the aesthetic value is not retain in the TL. The procedure of modulation is applied in changing the point of view of the message.

The $9^{\text {th }}$ line 'She's curled to the phone' is equivalent to 'gadis itu melingkar menempel ke telepon'. The SL 'she has curled to the phone' means that she has placed her ear closely to the phone the equivalent in the TL is a descriptive equivalent by stating that 'gadis itu melingkar menempel ke telepon'. The $10^{\text {th }}$ line 'listening to that impossible music' is translated to 'mendengarkan musik yang masyaalah itu'; the word 'impossible' is translated into 'masyaalah' is a transposition procedures in which the translator changed the point of view of the meaning of impossible in 'masyaalah'; if it is applying back-translation the word 'masyaalah' means 'for goodness 'sake!

The $11^{\text {th }}$ line 'a smile curving her face' is translated into 'senyum melengkung di wajahnya'; the personification in the SL is replaced by the personification in the TL. The $12^{\text {th }}$ line 'I wonder if he has enough change' is translated into 'Entahlah, apa lelaki itu punya cukup uang receh'; the descriptive equivalent procedure is applied in which the SL is transferred into a more detail as the pronoun 'he' is translated into 'lelaki itu' referring to the previous statement that particular boy who has made a phone call.

Line $13^{\text {th }}$, for all those extensions' is translated into 'untuk telepon jarak jauh itu' the procedure of descriptive equivalent and shift are applied. 'Extensions' in the SL means 'the long distance call'; it is translated into telepon jarak jauh which is a descriptive equivalent by describing the word 'extensions' in the TL. The prepositional phrase of the SL (line 13) comprises of Prep + all (quantifier) + demonstrative pronoun $+\mathrm{N}$ (plural) and the translation consists of prep $+\mathrm{N}+\mathrm{N}+$ adj. + demonstrative pronoun.

And the last line of the $2^{\text {nd }}$ stanza, line $14{ }^{~ ' C o u l d ~ h e ~ r e-~}$ verse the charge?' is transferred into 'Apa dia minta pacarnya yang membayar? The source line 'Could he reverse the charge' means 'he might ask his fiancée to pay for the call he did; the procedure of descriptive equivalent is applied.

\section{Analysis of Translation Procedures of the Third Stanza}

On the Table 3 the writer just mentioned the name of the boy who made the S.T.D call is boy called Hugh Adamson, expressing his sorrow that his old father is dying, his mother is dead and his girlfriend is away. This sorrowfulness mood is expressed in the lines of the third stanza.

Line 15 'Somebody called Hugh Adamson 'is transferred into 'Seseorang bernama Hugh Adamson'; the procedure of equivalent is applied. Line 16 'blares out a nocturne in a phone box' is a hyperbole an exaggeration of the sounds of the nocturne in the phone box by stating the word blares which has the meaning loud sounds repeatedly. It is translated into a hyperbole 'meraungkan nokturno di gardu telepun 'in the TL; in which the translator applied the word (verb) 'meraungkan' replacing the sounds made by a dog at night repeatedly. The sense of 'blare'(verb) is nearest equivalent in the TL with the verb 'meraung'. Line 17 'His father's old and dying'; the SL sentence is comprises $\mathrm{S}+\mathrm{P}+\mathrm{C}$ (old and dying) is translated into 'Ayahnya

Table 2. Stanza 2

\begin{tabular}{|c|c|c|}
\hline Line & SL & TL \\
\hline 8 & I can imagine... & $\begin{array}{l}\text { Bisa kubayangkan... } \\
\text { can I- imagine }\end{array}$ \\
\hline 9 & She's curled to the telephone & $\begin{array}{l}\text { Gadis itu melingkar menempel ke telepon } \\
\text { girl that curl attach to telephone }\end{array}$ \\
\hline \multirow[t]{2}{*}{10} & listening to that impossible music & $\begin{array}{l}\text { Mendengar musik yang masyaalah } \\
\text { itu }\end{array}$ \\
\hline & & $\begin{array}{l}\text { listen music which for goodness } \\
\text { sake that }\end{array}$ \\
\hline 11 & A smile curving her face & $\begin{array}{llll}\text { Senyum } & \text { melengkung } & \text { di } & \text { wajahnya } \\
\text { smile } & \text { curve } & \text { in face-her }\end{array}$ \\
\hline 12 & I wonder if he has enough change & $\begin{array}{l}\text { Entahlah, apa lelaki itu punya cukup uang receh } \\
\text { uncertain what man that has enough money small }\end{array}$ \\
\hline 13 & For all those extensions. & $\begin{array}{l}\text { Untuk telepon jarak jauh itu. } \\
\text { for telephone distance long that }\end{array}$ \\
\hline 14 & Could he reverse the charge? & $\begin{array}{l}\text { Apa dia minta pacar-nya yang membayar? } \\
\text { What he ask fiancée -his who pay }\end{array}$ \\
\hline
\end{tabular}


Table 3. Stanza 3

\begin{tabular}{|c|c|c|}
\hline Line & SL & TL \\
\hline 15 & Somebody called Hugh Adamson & $\begin{array}{l}\text { Seseorang bernama Hugh Adamson } \\
\text { Someone named Hugh Adamson }\end{array}$ \\
\hline 16 & Blares out a nocturne in a phone box. & $\begin{array}{lll}\text { Meraungkan } & \text { nokturno di gardu telepun } \\
\text { hauling } & \text { nocturne at box phone }\end{array}$ \\
\hline 17 & His father`s old and dying & $\begin{array}{l}\text { Ayahnya tua dan sekarat } \\
\text { Father-his old and dying }\end{array}$ \\
\hline 18 & His mother`s dead, his girl`s away, & $\begin{array}{ll}\text { Ibunya sudah } & \text { meninggal } \\
\text { pacarnya } & \text { jauh } \\
\text { mother -his } & \text { perfect marker } \\
\text { dead fiancée -his } & \text { far }\end{array}$ \\
\hline 19 & He`s very sad, his nocturne `s very sad, & $\begin{array}{l}\text { Ia pun pilu, nokturno-nya pun pilu, } \\
\text { He part. sad nocturne-his part. sad }\end{array}$ \\
\hline 20 & His trombone blares and flares and says, & $\begin{array}{l}\text { Trombonenya meraung dan menjerit dan berkata } \\
\text { trombone-his haul and scream and say }\end{array}$ \\
\hline 21 & "He`s very sad, yair, yair, he`s verysad" & 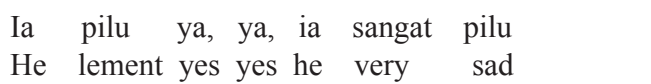 \\
\hline
\end{tabular}

Table 4. Stanza 4

\begin{tabular}{|c|c|c|}
\hline Line & SL & TL \\
\hline 22 & Maybe he`s only playing to a friend & $\begin{array}{ll}\text { Mungkin ia memainkan-nya untuk } \\
\text { seorang teman } & \\
\text { Maybe he play-it } & \text { for } \\
\text { a } & \text { friend }\end{array}$ \\
\hline 23 & In East St Kilda & $\begin{array}{l}\text { Di east ST Kilda } \\
\text { in East ST Kilda }\end{array}$ \\
\hline 24 & Maybe he hasn't any change & $\begin{array}{l}\text { Mungkin ia tak punya uang receh } \\
\text { maybe he no have money small }\end{array}$ \\
\hline 25 & $\begin{array}{l}\text { Someone is playing a trombone ... } \\
\text { impossible }\end{array}$ & $\begin{array}{l}\text { Seseorang sedang meniup trombone... masyaalah } \\
\text { Someone in progress blow trombone impossible }\end{array}$ \\
\hline 26 & In the phone box with the door shut & $\begin{array}{l}\text { Di gardu telpun pintunya ditutup } \\
\text { In box telephone door-its shut (pass.) }\end{array}$ \\
\hline 27 & I have no idea who he is. I am waiting & $\begin{array}{ccll}\text { Aku tak tahu siapa dia. Aku menanti } \\
\text { I } & \text { not know who he. I } & \text { wait }\end{array}$ \\
\hline 28 & For my phone to ring. I like this music & $\begin{array}{lllll}\text { Telepunku } & \text { berdering. Aku suka music ini; } \\
\text { telephone-my } & \text { ring. } & \text { I like music this } \\
\end{array}$ \\
\hline
\end{tabular}

tua dan sekarat ; the procedure of shift is applied it is due to the different system of the SL and the TL. The SL sentence (S + P+ $\mathrm{C}$ ) is translated into $\mathrm{S}+\mathrm{P}$ (is realized by adjective).

Related to line 17, Line 18 expresses in more detail the sorrow of the boy by the statement of 'his mother's dead, his girl's away' is translated into 'ibunya sudah meninggal, pacarnya jauh '; the procedures of shift is also applied. The SL' his mother's dead $(\mathrm{S}+\mathrm{P}+\mathrm{C})$ is translated into 'ibunya sudah meninggal $(\mathrm{S}+$ aspect marker past $+\mathrm{P})$; and the SL sentence 'his girl's away' $(\mathrm{S}+\mathrm{P}+\mathrm{C})$ is translated into 'pacarnya jauh' $(\mathrm{S}+\mathrm{P})$. Line 19 'he's very sad, his nocturne's very sad; the condition of the sorrow experienced by the boy event worse in which it is stated that even his nocturne is also sad. The equivalent transfer in the TL is 'Ia pun pilu, nokturnonya pun pilu; the translator translated the SL into an hyperbole in the TL, by stating the word 'pilu' twice and the existence of the particle 'pun' to exaggerate the condition of the sadness; it is not merely sad but the feeling of deep sorrow experience he faced. The personification in line 20 his trombone blares and flares and says, ' is translated into a personification in the TL'trombonenya meraung dan menjerit dan berkata: 'Trombone' in the SL is a non-human having the sound created by human in the word 'says' (personification); Trombone in the TL is a non-human have the characteristic of human like which crates the sound of 'meraung' (hauling), menjerit (cry),berkata (say). And the last line of the $3^{\text {rd }}$ stanza is a hyperbole 'He's very sad, yair, yair, he 's very sad' is translated into a hyperbole in the TL 'Ia pilu, ya, ya, ia sangat pilu'.

\section{Analysis of Translation Procedures of the Fourth Stanza}

In the Table 4 the writer is guessing that the boy who played the trombone to his girlfriend near a place in Melbourne East St Kilda, and expressing his doubt about the boy. The writer is imagining himself waiting for his phone to ring as he loves the music that he has heard from the corner phone box.

The fourth stanza, which is the last stanza begins with the statement of line 22 'Maybe he 's only playing to a 
friend' is translated into 'Mungkin ia memainkannya untuk seorang teman'; the procedure of equivalent is applied. Line 23 ' in East St Kilda' is translated into 'di East ST Kilda '; the procedure of equivalent is also applied. Line 24 'Maybe he hasn 't any change' is translated into 'Mungkin ia tak punya uang receh'; the procedure of shift is applied in translating 'the noun 'change' into 'uang receh' (NP) it is due to different system of the language. Line 25 'Someone is playing a trombone ...impossible' is the same as the previous line, which is the first line in the first stanza where the translator applied the procedure of shift and the translation of 'impossible 'into 'masyaalah' is applying the procedure of transposition as in the line 10 in the second stanza.

Line 26 the prepositional phrase 'in the phone box with the door shut is translated into prepositional phrase in the TL` di gardu telpun pintunya ditutup ' by applying procedure of shift in the translation of 'the door' into 'pintun$y a$; ' the door' in the TL signifies the door of the phone box in order to achieve the closest equivalent meaning; the use of possessive -nya is attached after the noun 'pintu'. Line 27 'I have no idea who he is. I am waiting' is translated into 'Aku tak tahu siapa dia. Aku menanti the procedure of transposition and shift are applied. The translation of 'I have no idea 'into 'Aku tak tahu', by transposing the meaning of the SL into TL. The SL sentence 'I am waiting ' $(\mathrm{S}+\mathrm{P})$ is in the state of progress into $\mathrm{TL}{ }^{\prime} A k u$ menanti $(\mathrm{S}+\mathrm{P})$ ', 'menanti' does not imply the state is in progress due to the different language structure of the TL. The last line is line 28 'for my phone to ring. I like this music' is translated into 'telepunku berdering. Aku suka musik ini'; the procedure of shift and equivalent are applied. The prepositional phrase 'for my telephone to ring; ' is shifted into 'telepunku berdering '. And the translation of sentence 'I like this music' $(\mathrm{S}+\mathrm{P}+\mathrm{O})$ into 'Aku suka musik ini $(\mathrm{S}+\mathrm{P}+\mathrm{O})$; there is a shift in the $\mathrm{NP}(\mathrm{O})$ of the $\mathrm{SL}$ 'this music' (demonstrative pronoun $+\mathrm{N} /$ head) while the 'musik ini' NP $(\mathrm{O})$ of the TL comprises of N/head + demonstrative pronoun.

\section{CONCLUSION}

Based on the previous discussion above, it can be concluded that the translator applied a number of procedures in order to retain the meaning of the SL in the TL namely: shifts are the most applied due to the difference in the language system between SL and TL, and followed by descriptive equivalent, modulation, cultural equivalent, functional equivalent, and transposition.

The translation of the SL figurative expressions; personifications and hyperboles are translated into figurative expressions; personifications and hyperboles in the TL as well, in this case the translator tries to retain the aesthetic value in order to gain similar impressions of the SL message of the poem in the TL. Even one of the data shows that non-hyperbole in the SL is transferred into a hyperbole in the data of the third stanza line 19.

\section{REFERENCES}

Aiwei, S. (2005). Translatability and Poetic Translation. Translatum Journal, 5.

Bassnet, S. \& Andre, L. (Eds.) (1995). Translation, History and Culture. USA: Chassell.

Brissenden, R.F \& Sapardi J.D (Eds.). (1991). Mendorong Jack Kunti kunti: Serpihan Sajak dari Australia Bi-lingual edition. Jakarta. Yayasan Obor Indonesia.

Larson L. M. (1984). Meaning -Based Translation. New York: University Press of America, Inc.

Newmark, P. (1988). A Textbook of Translation. New York: Prentice Hall.

Newmark, P. (1998). More Paragraphs on Translation. UK: Multilingual Matters Ltd.

Nida, E.A., \& Charles, R. T. (1969). The Theory and Practice of Translation. Leiden: EJ. Brill.

Venuti, L. (2011). Introduction: Poetry and Translation. Translation Studies Journal, 4(2).

Vinay, J. P. \& Darbelnet, J. (2000). A Methodology for Translation in Venuti Eds. The Translation Studies Readers. New York: Routledge. 